\title{
KUALITAS INFORMASI AKUNTANSI PADA BAITUL MAAL WAT TAMWIL DI MALANG RAYA
}

\author{
Ria Saifulloh \\ Ulfi Kartika Oktaviana
}

\author{
Fakultas Ekonomi, Universitas Islam Negeri Maulana Malik Ibrahim Malang \\ Jl. Gajayana 50 Malang Telp. 0341-551354 \\ Email: Riansaiful5@gmail.com
}

Abstract

Accounting information is a tool that can help the management of a company especially BMT in Malang in running the company properly and continuously. Thus, it must be supported with good quality of accounting information. Quality information can be obtained by referring to the standard of the qualitative characteristics of financial statements. This study uses a quantitative approach with descriptive methods. The object of research were 10 BMTs in which each BMT was given questionnaires and interviews. After the questionnaire data was obtained, it was processed and analyzed with the help of SPSS 16 statistical tools. The results showed that there are significant effect between the qualitative characteristics of accounting information which is understandable, relevant, reliable and comparable to the quality of accounting information on BMT Greater Malang. This is due to the respondents from each BMT also have the ability in economics and accounting as an undergraduate so that what is presented in the accounting information is already qualified and is in accordance with the results of the statistical analysis by SPSS. It can be concluded that the quality of accounting information on BMT in Greater Malang is quite good because it has met the qualitativecharacteristics of accounting information.

Keywords: qualitative characteristics, quality of accounting information, BMT 
Abstrak

Informasi Akuntansi merupakan alat yang dapat membantu manajemen suatu perusahaan khususnya BMTdi Malang dalam menjalankan perusahaannya dengan baik dan berkesinambungan. Maka dari itu harus didukung dengan kualitas informasi akuntansi yang baik. Kualitas informasi bisa didapat dengan mengacu standar dari karakteristik kualitatif laporan keuangan. Penelitian ini menggunakan pendekatan kuantitatif dengan metode deskriptif. Objek penelitian sebanyak 10 BMT dengan masing-masing BMT disebar kuisioner dan wawancara. Kemudian setelah data kuisioner diperoleh akan diproses dan dianalisis data dengan bantuan alat statistik yaitu SPSS 16. Dari hasil penelitian menunjukkan bahwa terdapat pengaruh antara karakteristik kualitatif informasi akuntansi yaitu dapat dipahami, relevan, dapat diandalkan dan dapat dibandingkan terhadap kualitas informasi akuntansi pada BMT Malang Raya. Hal ini disebabkan responden dari masing-masing BMT juga memiliki kemampuan ekonomi dan akuntansi sebagai seorang sarjana sehingga apa yang disampaikan dalam informasi akuntansi sudah berkualitas dan sesuai dengan hasil dari analisis statistik SPSS. Dapat ditarik kesimpulan bahwa kualitas informasi akuntansi pada BMT di Malang tergolong baik karena sudah memenuhi karakteristik kualitatif informasi akuntansi.

Kata kunci: karakteristik kualitatif, kualitas informasi akuntansi, BMT

\section{PENDAHULUAN}

Informasi Akuntansi merupakan alat yang dapat membantu manajemen suatu perusahaan dalam menjalankan perusahaannya dengan baik dan berkesinambungan. Informasi akuntansi inilah yang nantinya menjadi dasar bagi pihak-pihak yang berkepentingan baik internal maupun eksternal untuk mengambil keputusan. Keputusan yang diambil akan tepat dan akurat bila sumber informasi akuntansi yang dihasilkan berkualitas. Untuk itu kualitas informasi akuntansi keuangan harus memenuhi standar yang baik. Kualitas tersebut dapat diketahui berdasar beberapa karakteristik kualitatif yang dijelaskan oleh AAOIFI (Accounting and Auditing Organization for Islamic Financial Institutions) Statement Nomor 2 diantaranya relevansi, keandalan, dapat diperbandingkan, konsistensi, dan dapat dipahami. (Nurmala, 2009).

Dalam Kerangka Kerja Konseptual untuk Pelaporan Keuangan Kieso berbasis IFRS disebutkan bahwa untuk informasi akuntansi yang berkualitas harus memenuhi standar karakteristik kualitatif yang relevansi dan faithful representation sebagai kualitas dasar (Fundamental Qualities) dari informasi akuntansi yang akan dihasilkan, serta comparability, verifiability, timelines, understandability sebagai kualitas penunjang (Enhacing Qualities) dari informasi akuntansi yang akan dihasilkan (Kieso, 2013). Sedangkan menurut Kerangka Dasar Penyusunan dan 
Penyajian Laporan Keuangan Syariah (KDPPLK) Syariah paragraf 44 menyatakan bahwa ada empat karakteristik kualitatif pokok laporan keuangan yaitu: dapat dipahami, relevan, keandalan, dan dapat diperbandingkan. (IAI, 2015). Standar dari KDPPLK Syariah inilah yang nanti akan digunakan sebagai variabel penelitian.

Karakter kualitatif dapat dipahami maksutnya informasi yang ditampung dalam laporan keuangan harus mudah untuk segera dapat dipahami oleh pemakai. Relevan bisa dikatakan bahwa informasi tersebut harus materialis sehingga berguna dalam mempengaruhi keputusan ekonomi. Keandalan informasi jika bebas dari pengertian yang menyesatkan, kesalahan material, dan dapat diandalkan pemakainya sebagai penyajian yang tulus atau jujur (faithful representation) dari yang seharusnya disajikan atau yang secara wajar diharapkan dapat disajikan. Kemudian dapat dibandingkan, pemakai harus dapat memperbandingkan laporan keuangan perusahaan antar periode untuk mengidentifikasi kecenderungan (trend) posisi dan kinerja keuangan. (IAI, 2015)

Dengan telah ditetapkannya standar diatas dalam menyajikan laporan keuangan akan menambah kualitas informasi akuntansi tersebut. Sejauh mana kualitas informasi akuntansi yang disajikan pada laporan keuangan nantinya dapat digunakan sebagai dasar dalam pengambilan keputusan ekonomi. Yang mana tujuan akuntansi secara keseluruhan adalah memberikan informasi yang dapat digunakan dalam pengambilan keputusan (Hery, 2012). Keputusan ekonomi yang tepat dalam dunia modern sangat penting, dimana kualitas informasi yang baik akan mengarahkan masa depan dunia bisnis. Hal ini karena kualitas informasi yang baik dapat membawa kesuksesan, sementara kualitas informasi yang buruk dapat menyebabkan kegagalan usaha. (Romney,2006)

BMT (Baitul Mal wat Tamwil) sebagai lembaga mikro keuangan syariah yang berbentuk hukum koperasi juga berkewajiban untuk melaporkan laporan keuangannya ke anggotanya. Meskipun berbentuk hukum koperasi sesuai UU Nomor 25 Tahun 1992 tentang Pelaksanaan Usaha Simpan Pinjam oleh Koperasi (Neni, 2010). BMT juga lembaga yang menjalankan operasionalnya sesuai hukum syariah, sehingga dalam pelaporan keuangannya harus mengikuti Pernyataan Standar Akuntansi Keuangan Syariah. IAI telah menerbitkan 11 PSAK khusus keuangan syariah yaitu PSAK 101 sampai PSAK 111, dimana PSAK tersebut digunakan sebagai standar dalam pelaporan keuangan syariah. (IAI,2015)

BMT bisa dikatakan sebagai lembaga pengumpul dan penyalur dana layaknya bank syariah dan juga sebagai penghimpun dari Maal (zakat, infaq, shodaqoh). (Djazuli, 2002). Pemerintah melalui Kementrian Koperasi dan UKM menyatakan koperasi jasa keuangan syariah dalam bentuk BMT berkembang sangat signifikan. Hal ini tidak lepas dari perkembangan kinerja dari BMT di Indonesia tahun 2015 telah mencapai aset sebesar Rp 4,7 triliun dan jumlah pembiayaan sebesar Rp 3,6 triliun. (Republika, 2015). 
Penelitian tentang kualitas informasi akuntansi sebelumnya dilakukan oleh Aditya (2014) pada Rumah Sakit Daerah Ungaran. Penelitian ini dilakukan pengujian apakah karakteristik kualitatif relevan, terpercaya, lengkap, tepat waktu dan dapat dimengerti berpengaruh terhadap kualitas informasi akuntansi. Dan dari hasil penelitian dijelaskan karakteristik tersebut secara bersama-sama berpengaruh signifikan terhadap kualitas informasi akuntansi. Sedangkan hasil dari penelitian Diyana dan Jalianto (2014) dengan metode berbeda yaitu dengan metode kualitatif diketahui bahwa laporan keuangan yang disajikan oleh PT. PLN (Persero) sangat berkualitas dikarenakan telah sesuai dengan standar akuntansi pemerintah dimana kualitas laporan keuangan ditimbulkan oleh beberapa faktor seperti relevan, akurat, dan tepat waktu dalam pelaporannya.

Indriani dan Khoiriyah (2010) menganalisis pengaruh relevansi nilai, ketepatwaktuan, dan konservatisme terhadap kualitas laporan keuangan. Hasilnya ketiga faktor tersebut secara bersama berpengaruh terhadap kualitas laporan keuangan. Sedangkan penelitian dengan objek BMT pernah dilakukan Nurmala dan Evi (2009) yaitu pada BMT yang berada di Bandar Lampung. Dari hasil penelitian diketahui bahwa kualitas informasi akuntansi dalam pengukuran penilaian menggunakan standar dari AAOIFI yaitu relevance, reliability, comparability, consistency, understandability berpengaruh signifikan terhadap kualitas informasi akuntansi. Penelitian terhadap BMT di Bandar Lampung ini nantinya akan dilanjutkan untuk penelitian tentang kualitas informasi akuntansi pada BMT yang ada di Jawa khususnya Malang Jawa Timur, dimana di Jawa Timur sendiri belum pernah dilakukan penelitian tentang kualitas informasi akuntansi. Dalam penelitian selanjutnya ini digunakan standar karakteristik yang berbeda dengan sebelumnya yang mana menggunakan pendekatan karakteristik kualitatif informasi akuntansi yang dikeluarkan IAI dalam KDPPLK yaitu dapat dipahami, relevan, keandalan, dan dapat dibandingkan. Relevan mengandung nilai prediktif, nilai konfirmasi, materialitas, dan tepat waktu. Keandalan mengandung nilai dapat diperiksa, objektif, menyajikan yang sebenarnya. Kemudian dapat dibandingkan mengandung nilai konsistensi. (IAI, 2015)

Maka dari itu peneliti tertarik untuk melakukan penelitian dimana akan membahas lebih lanjut tentang: Apakah karakteristik kualitas informasi akuntansi dapat dipahami (understandable) berpengaruh terhadap kualitas informasi akuntansi pada BMT di Malang?; Apakah karakteristik kualitas informasi akuntansi relevan berpengaruh terhadap kualitas informasi akuntansi pada BMT di Malang?; Apakah karakteristik kualitas informai akuntansi keandalan (reabilitas) berpengaruh terhadap kualitas informasi akuntansi pada BMT di Malang?; Apakah karakteristik kualitas informasi akuntansi dapat dibandingkan (komparabilitas) berpengaruh terhadap kualitas informasi akuntansi pada BMT di Malang?; Apakah karakteristik kualitas informasi akuntansi dapat dipahami, relevan, dapat diandalkan, dan dapat dibandingkan berpengaruh secara bersama-sama terhadap kualitas informasi akuntansi pada BMT di Malang? 


\section{Kajian Teoritis}

Penelitian ini memakai teori kegunaan informasi (decision-usefulnesstheory). Salah satu orang yang pertama kali menggunakan paradigma kegunaan keputusan (decision usefulness) adalah Chambers (dalam Belkoui, 2001), mengatakan ....."Oleh karenanya, akibat yang wajar dari asumsi manajemen rasional adalah bahwa seharusnya ada sistem yang menyajikan suatu informasi; seperti sistem yang diperlukan baik untuk dasar pembuatan keputusan atau dasar untuk memperoleh kembali konsekuensi keputusan. Sistem yang menyajikan informasi secara formal akan menyesuaikan dengan dua dalil umum. Pertama adalah kondisi dari setiap wacana ilmiah, sistem seharusnya secara logika konsisten; tidak ada aturan atau proses yang dapat bertentangan dengan setiap aturan atau proses lainnya. Kedua muncul dari pemakai laporan akuntansi sebagai dasar pembuatan keputusan dari konsekuensi praktik, informasi yang dihasilkan oleh setiap sistem seharusnya relevan dengan berbagai bentuk pembuatan keputusan yang diharapkan dapat digunakan.

Kegunaan-keputusan informasi akuntansi mengandung komponen-komponen yang perlu dipertimbangkan oleh para penyaji informasi akuntansi agar cakupan yang ada dapat memenuhi kebutuhan para pengambil keputusan yang akan menggunakannya. SFAC No. 2 tentang Qualitative Characteristics ofAccounting Information menggambarkan hirarki dari kualitas informasi akuntansi dalam bentuk kualitas primer, kandungannya dan kualitas sekunder. Kualitas primer dari informasi yang berguna dalam pengambilan keputusan ekonomi adalah nilai relevan (relevance) dan reliabilitas (reliability). FASB menyatakan bahwa nilai relevan dan reliabilitas adalah dua kualitas utama yang membuat informasi akuntansi berguna dalam pengambilan keputusan.

Kegunaan informasi dalam islam, dijelaskan bahwa dalam menerima suatu informasi harus terlebih dahulu meneliti suatu informasi tersebut. Dari informasi yang baik maka akan bisa berguna untuk orang yang membutuhkan. Pada zaman Nabi kegunaan suatu informasi sangat penting bagi jalannya keislaman pada saat itu. Saat zaman khalifah Usman al Quran dan al Hadist mulai dilakukan penulisan atau pembukuan. Menjadi sangat penting jika informasi yang didapat sangat terpercaya. Sama halnya dengan yang dilakukan di akuntansi dimana sistem pembukuan laporan keuangan menjadi patokan utama dalam menyampaikan informasi keuangan suatu perusahaan. Informasi dalam al Quran bisa dilihat dalam surat AlHujurat ayat 6:

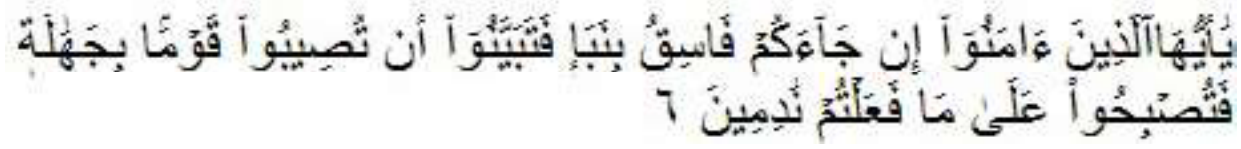

El-Muhasaba, Vol. 7, No 2, Juli 2016 
Hai orang-orang yang beriman, jika datang kepadamu orang fasik membawa suatu berita, maka periksalah dengan teliti agar kamu tidak menimpakan suatu musibah kepada suatu kaum tanpa mengetahui keadaannya yang menyebabkan kamu menyesal atas perbuatanmu itu. (Al Hujurat:6).

Menurut tafsir Ibnu Katsir dalam ayat ini dijelaskan bahwa Allah SWT memerintahkan (kaum mukmin) untuk memeriksa dengan teliti berita dari orang fasik, dan hendaklah mereka bersikap hati-hati dalam menerimanya dan jangan menerimanya dengan begitu saja, yang akibatnya akan membalikkan kenyataan. Orang yang menerima dengan begitu saja berita darinya, berarti sama dengan mengikuti jejaknya. Sedangkan Allah SWT telah melarang kaum mukmin mengikuti jalan orang-orang yang rusak.

Berangkat dari pengertian inilah ada sejumlah ulama yang melarang kita menerima berita (riwayat) dari orang yang tidak dikenal, karena barangkali dia adalah orang yang fasik. Tetapi sebagian ulama lainnya mau menerimanya dengan alasan bahwa kami hanya diperintahkan untuk meneliti kebenaran berita orang fasik, sedangkan orang yang tidak dikenal (majhul) masih belum terbukti kefasikannya karena dia tidak diketahui keadaannya.

Kaitannya dengan informasi akuntansi adalah dalam menyajikan informasi akuntansi supaya disajikan dengan baik dan sesuai standar yang benar sehingga pihak-pihak internal maupun eksternal perusahaan yang membutuhkan informasi tersebut bisa bermanfaat dengan baik.

\section{Karakteristik Kualitatif Informasi Akuntansi}

Dalam Kerangka Kerja Konseptual untuk Pelaporan Keuangan oleh Kieso menjelaskan bebarapa karakteristik kualitatif dari informasi akuntansi. IASB mengidentifikasi karakteristik kualitatif informasi akuntansi yang membedakan informasi yang lebih baik (lebih berguna) dari informasi lebih rendah (kurang berguna) untuk tujuan pengambilan keputusan. (Kieso, 2013).

\section{a. Kualitas Dasar (Fundamental Qualities)}

1. Relevansi

Relevansi adalah salah satu dari dua sifat mendasar yang membuat informasi akuntansi berguna untuk pengambilan keputusan. Relevansi bisa diketahui apabila informasi akuntansi tersebut mempunyai nilai prediktif untuk keputusan ekonomi waktu yang akan datang dan nilai konfirmasi.

2. Faitful Representation

Representasi setia berarti bahwa angka dan deskripsi sesuai apa yang benar-benar ada atau terjadi. Representasi yang dimaksud adalah bahwa infomasi akuntansi harus complete, netral, dan jauh dari kesalahan. 


\section{b. Kualitas Pendukung (Enhancing Qualities)}

Membedakan informasi yang lebih berguna dari informasi yang kurang berguna.

Terdiri dari informasi yang berkualitas harus dapat dibandingkan, dapat diverifikasi, tepatwaktu dan dapat dimengerti.

Dalam Kerangka Kerja Konseptual untuk Pelaporan Keuangan karakteristik kualitatif informasi akuntansi dijelaskan oleh IASB mengidentifikasi karakteristik kualitatif informasi akuntansi yang membedakan informasi yang lebih baik (lebih berguna) dari informasi lebih rendah (kurang berguna) untuk tujuan pengambilan keputusan. Dimana karakteristik kualitatif terbagi menjadi dua kualitas primer dan kualitas sekunder, yaitu: (Belkaoui, 2006;238).

\section{a. Kualitas Primer}

Suatu informasi akuntansi akan dikatakan memenuhi kualitas primer apabila informasi tersebut relevan (relevant) dan dapat dipercaya (reliable).

1. Relevansi

Agar bermanfaat, informasi harus relevan untuk memenuhi kebutuhan pemakai dalam proses pengambilan keputusan. Suatu informasi akan dianggap memiliki nilai relevansi apabila ada atau tidaknya informasi tersebut akan membuat perbedaan dalam pengambilan keputusan. Selain itu, relevansi informasi juga dapat dinilai berdasarkan hubungan informasi tersebut dengan maksud penggunanya. Untuk dapat dianggap relevan, suatu informasi harus mengandung tiga nilai yaitu:

a) Nilai prediktif (predictive value) Informasi akan dikatakan mengandung nilai prediktif apabila informasi tersebut dapat membantu pengguna untuk memberikan prediksi mengenai dampak atau akibat dari peristiwa masa lalu, masa sekarang, dan masa depan.

b) Nilai umpan balik (feedback value) Suatu informasi akan mengandung nilai umpan balik atau feedback value ketika informasi tersebut dapat membantu pengguna dalam memberikan umpan balik untuk memperkuat atau memperbaiki keputusan.

c) Nilai ketepatan waktu (timeliness)

Nilai ketepatan waktu merupakan unsur utama dalam faktor penentu relevansi suatu informasi akuntansi. Suatu informasi dianggap mengandung nilai ketepatan waktu apabila informasi tersedia pada saat informasi tersebut masih memiliki pengaruh dalam pengambilan keputusan oleh pengguna. Dengan demikian, ketepatan waktu merupakan suatu nilai yang harus terkandung pada informasi keuangan. Informasi yang tepat waktu berarti jangan sampai informasi yang disampaikan sudah basi atau sudah menjadi rahasia umum. 
Suatu informasi akan menjadi tidak relevan jika tidak tepat waktu dan akan kehilangan kesempatan untuk mempegaruhi keputusan. Ketepatan waktu tidak menjamin relevansi, tetapi relevansi informasi tidak dimungkinkan tanpa ketepatan waktu. Informasi mengenai kondisi dan posisi perusahaan harus secara cepat dan tepat waktu sampai ke pemakai laporan keuangan. Ketepatan waktu mengimplikasikan bahwa laporan keuangan seharusnya disajikan pada suatu interval waktu, untuk menjelaskan perubahan dalam perusahaan yang mungkin mempengaruhi pemakai informasi dalam membuat prediksi dan keputusan (Hendriksen: 2002).

Relevan kaitannya dengan integrasi Islam sendiri bisa dijelaskan dalam surat At-Taubah 106.

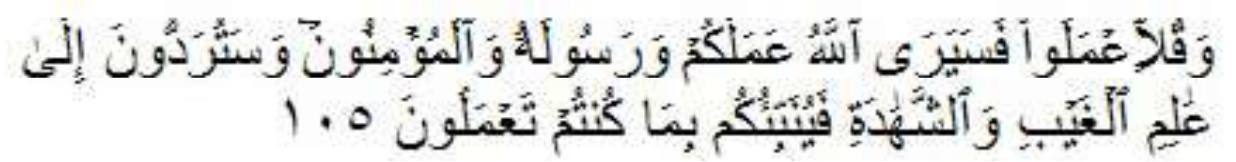

Dan Katakanlah: "Bekerjalah kamu, maka Allah dan Rasul-Nya serta orang-orang mukmin akan melihat pekerjaanmu itu, dan kamu akan dikembalikan kepada (Allah) Yang Mengetahui akan yang ghaib dan yang nyata, lalu diberitakan-Nya kepada kamu apa yang telah kamu kerjakan (At Taubah 105)

Dalam tafsir Ibnu katsir dijelaskan Mujahid mengatakan bahwa hal ini merupakan ancaman dari Allah terhadap orang-orang yang menentang perintahperintah-Nya, bahwa amal perbuatan mereka kelak akan ditampilkan di hadapan Allah SWT dan Rasul-Nya serta orang-orang mukmin.

Hubungannya pada informasi yang relevan adalah penyampaian infomasi haruslah dilakukan secara relevan yang mana apa yang tersampaikan harus bisa ditanggungjawabkan yang nantinya tujuan dari relevan adalah informasi akuntansi tersebut bisa berguna untuk pihak-pihak yang berkepentingan. Relevan juga di pengaruhi oleh hakikat dan tingkat materialitasnya. Materialitas ditentukan berdasarkan pengaruh kelalaian (ambang batas) terhadap keputusan ekonomi pemakai yang diambil atas dasar laporan keuangan. Oleh karena itu, materialitas dipengaruhi oleh besarnya kesalahan dalam mencantumkan atau pencatatan.

2. Keandalan (Reliable)

Suatu informasi harus dapat diandalkan dalam mendukung suatu pengambilan keputusan sehingga menghasilkan suatu keputusan yang solid, sesuai dengan kebutuhan dan keadaan perusahaan. Agar dapat diandalkan, informasi harus mengandung karakteristik berikut: 
a) Dapat diperiksa (verifiability)

Maksudnya adalah apabila ada dua orang melakukan pemeriksaan terhadap satu laporan keuangan yang sama dengan metode yang sama, maka akan memberikan satu kesimpulan yang juga sama.

b) Kejujuran Penyajian (representational faithfulness)

Bahwa angka-angka dan penjelasan yang disajikan bebar-benar terjadi.

c) Netral (neutrality)

Bahwa informasikan yang disajikan tidak boleh dipengaruhi oleh kepentingan pihak-pihak tertentu.

Keandalan dalam Islam merujuk pada bagaimana dalam menyampaikan amanat dengan jujur dan apa adanya. Seperti yang dijelaskan di surat AnNisa' ayat 58:

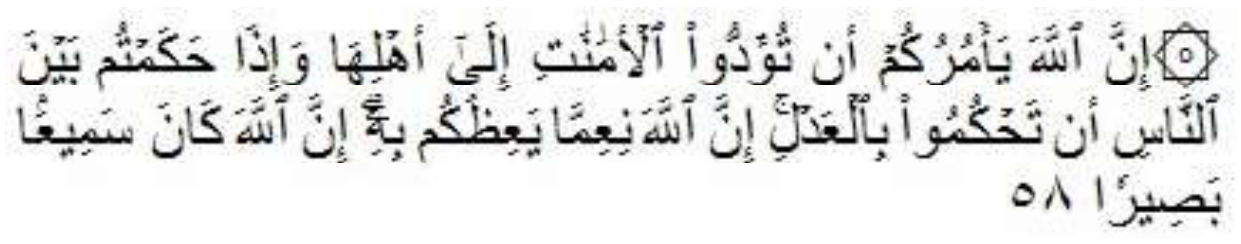

Sesungguhnya Allah menyuruh kamu menyampaikan amanat kepada yang berhak menerimanya, dan (menyuruh kamu) apabila menetapkan hukum di antara manusia supaya kamu menetapkan dengan adil. Sesungguhnya Allah memberi pengajaran yang sebaik-baiknya kepadamu. Sesungguhnya Allah adalah Maha Mendengar lagi Maha Melihat (An-Nisa';58)

Dalam Tafsir Quraish Shihab dijelaskan sesungguhnya Allah memerintahkan kalian, wahai orang-orang yang beriman, untuk menyampaikan segala amanat Allah atau amanat orang lain kepada yang berhak secara adil. Jangan berlaku curang dalam menentukan suatu keputusan hukum. Ini adalah pesan Tuhanmu, maka jagalah dengan baik, karena merupakan pesan terbaik yang diberikanNya kepada kalian. Allah selalu Maha Mendengar apa yang diucapkan dan Maha Melihat apa yang dilakukan. Dia mengetahui orang yang melaksanakan amanat dan yang tidak melaksanakannya, dan orang yang menentukan hukum secara adil atau zalim. Masing-masing akan mendapatkan ganjarannya.

Dalam kaitannya dengan informasi akuntansi yang andal adalah bahwa informasi yang dihasilkan haruslah sesuai dengan fakta yang ada. Dimana dalam informasi tersebut bisa dipegang amanatnya sebagai informasi yang benar dan bersih dari sifat-sifat kecurangan. Kualitas informasi akuntansi ini jika berpegang terhadap ayat tersebut akan menjadi informasi yang andal dan terpercaya. 


\section{b. Kualitas Sekunder}

Kualitas sekunder (secondary qualitative characteristic) adalah keterbandingan (comparability) dan konsistensi (consistecy). Suatu informasi akan menjadi lebih berguna apabila dapat dibandingkan dengan informasi sejenis dari perusahaan lainnya (keterbandingan) dan dapat dibandingkan dengan informasi serupa dalam satu perusahaan pada titik waktu yang berbeda (konsisten).

Berdasarkan KDPPLK Syariah dalam PSAK dijelaskan laporan keuangan yang berguna bagi pemakai informasi bahwa harus terdapat empat karakteristik kualitatif pokok yaitu dapat dipahami, relevan, keandalan, dan dapat diperbandingkan (IAI, 2015).

1. Dapat dipahami

Kualitas penting informasi yang ditampung dalam laporan keuangan adalah kemudahannya untuk segera dapat dipahami oleh pemakai.Untuk maksud ini, pemakai diasumsikan memiliki pengetahuan yang memadai tentang aktivitas ekonomi dan bisnis, akuntansi, serta kemauan untuk mempelajari informasi dengan ketekunan yang wajar. Namun demikian, informasi kompleks yang seharusnya dimasukkan dalam laporan keuangan tidak dapat dikeluarkan hanya atas dasar pertimbangan bahwa informasi tesebut terlalu sulit untuk dapat dipahami oleh pemakai tertentu.

2. Relevan

Informasi harus relevan untuk memenuhi kebutuhan pemakai dalam proses pengambilan keputusan. Informasi memiliki kualitas relevan kalau dapat mempengaruhi keputusan ekonomi pemakai dengan membantu mereka mengevaluasi peristiwa masa lalu, masa kini atau masa depan, menegaskan, atau mengkoreksi hasil evaluasi mereka dimasa lalu.

Peran informasi dalam peramalan (predictive) dan penegasan (confirmatory) berkaitan satu sama lain. Misalnya informasi struktur dan besarnya aset yang dimiliki bermanfaat bagi pemakai ketika mereka berusaha meramalkan kemampuan perusahaan dalam memanfaatkan peluang dan bereaksi terhadap situasi yang merugikan. Informasi yang sama juga berperan dalam memberikan penegasan (confirmatory role) terhadap prediksi yang lalu, misalnya tentang bagaimana struktur keuangan perusahaan diharapkan tersusun atau tentang hasil dari operasi yang direncanakan.

Informasi posisi keuangan dan kinerja di masa lalu seringkali digunakan sebagai dasar untuk memprediksi posisi keuangan dan kinerja masa depan dan hal-hal lain yang langsung menarik perhatian pemakai, seperti pembayaran dividen dan upah, pergerakan harga sekuritas dan kemampuan perusahaan untuk memenuhi komitmennya ketika jatuh tempo. Untuk memiliki nilai prediktif, informasi tidak perlu harus dalam bentuk ramalan eksplisit. Namun demikian, kemampuan laporan keuangan untuk membuat prediksi dapat ditingkatkan dengan penampilan informasi tentang transaksi dan peristiwa masa lalu. 
Misalnya nilai prediktif laporan laba-rugi dapat ditingkatkan kalau akun-akun penghasilan atau badan yang tidak biasa, abnormal dan jarang terjadi diungkapkan secara terpisah.

3. Keandalan

Informasi juga harus andal (reliable). Informasi memiliki kualitas andal jika bebas dari pengertian yang menyesatkan, material, dan dapat diandalkan pemakaiannya sebagai penyajian yang tulus atau jujur dari yang seharusnya disajikan atau yang secara wajar diharapkan dapat disajikan. Informasi mungkin relevan tetapi jika hakikat atau penyajiannya tidak dapat diandalkan maka penggunaan informasi tersebut secara potensial dapat menyesatkan. Misalnya jika tindakan hukum masih dipersengkatakan, mungkin tidak tepat bagi perusahaan untuk mengakui jumlah seluruh tuntutan tersebut dalam laporan posisi keuangan, meskipun mungkin tepat untuk mengungkapkan jumlah serta keadaan dari tuntutan tersebut.

4. Dapat dibandingkan

Pemakai harus dapat membandingkan laporan keuangan perusahaan antara periode untuk mengidentifikasi kecenderungan posisi dan kinerja keuangan. Pemakai juga harus dapat memperbandingkan laporan keuangan antara perusahaan untuk mengevaluasi posisi keuangan secara relatif. Oleh karena itu, pengukuran dan penyajian dampak keuangan, transaksi, dan peristiwa lain yang serupa harus dilakukan secara konsisten untuk perusahaan bersangkutan, antar periode perusahaan yang sama dan untuk perusahaan yang berbeda (IAI,2015). Dapat dibandingkan dalam Islam sendiri bisa diketahui bagaimana suatu informasi haruslah sesuai standar pengukuran yang telah ditetapkan dan taat pada asas yang telah ditetapkan sehingga informasi tersebut bisa dibandingkan satu sama lain. Seperti dalam QS Al-Israa' ayat 35:

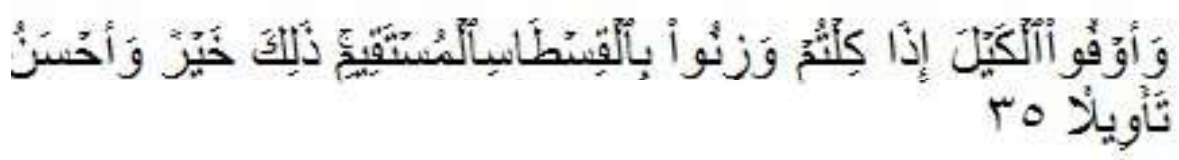

Dan sempurnakanlah takaran apabila kamu menakar, dan timbanglah dengan neraca yang benar. Itulah yang lebih utama (bagimu) dan lebih baik akibatnya (Al-Israa';35)

Tafsir Ibnu Katsir dijelaskan sempurnakanlah takaran yakni tidak boleh menguranginya di dalam neraca timbangan. Maka bisa ditarik kesimpulan dalam akidah akuntansi dalam konsep Islam dapat didefinisikan sebagai kumpulan dasar hukum yang baku dan permanen. Disimpulkan dari sumber-sumber Syariah Islam dan dipergunakan sebagai aturan oleh seorang akuntan dalam pekerjaannya, baik dalam pembukuan, analisis, pengukuran, pemaparan, maupun penjelasan, dan menjadi 
pijakan dalam menjelaskan suatu kejadian atau peristiwa. Sehingga dengan adanya sumber dasar hukum dalam pencatatan yang telah ditetapkan maka informasi akuntansi tersebut bisa konsisten dalam pencatatannya dan nantinya bisa untuk dibandingkan satu sama lainnya.
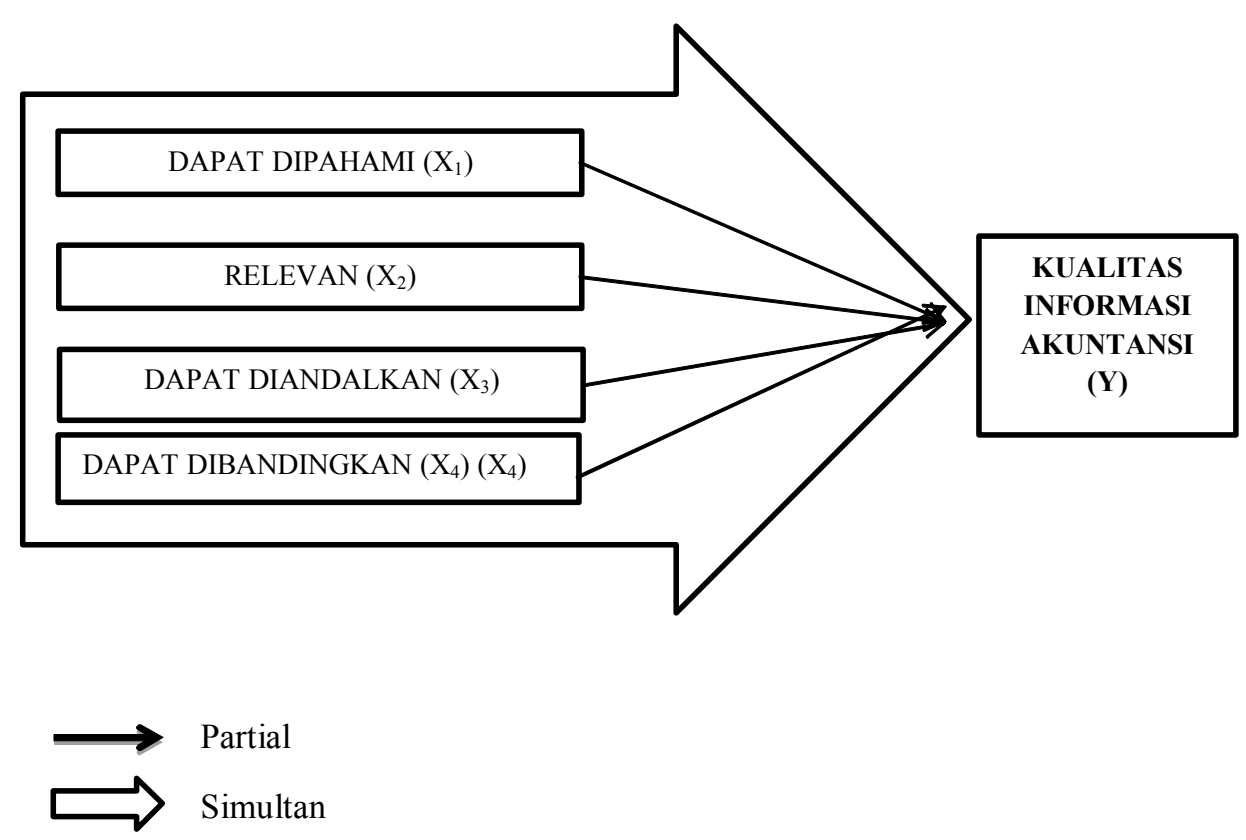

Gambar 1. Kerangka Konseptual

\section{Hipotesis Penelitian}

\section{Pengaruh Karakteristik Kualitas Informasi Akuntansi dapat Dipahami terhadap Kualitas Informasi Akuntansi}

Suatu informasi dikatakan bermanfaat apabila dapat dengan mudah dipahami oleh pihak pengguna dan dinyatakan dalam bentuk serta istilah yang disesuaikan dengan batas penggunaan pengguna (Sukmaningrum, 2012). Semakin dapat dipahami informasi yang disajikan dalam laporan keuangan oleh pengguna dan dinyatakan dalam bentuk serta istilah yang sesuai dengan batas pemahaman para pengguna maka semakin baik dan berguna kualitas informasi akuntansi tersebut (Widjajanto, 2004).

H1 : Karakteristik kualitas informasi akuntansi dapat dipahami berpengaruh secara signifikan terhadap kualitas informasi akuntansi. 


\section{Pengaruh Karakteristik Kualitas Informasi Akuntansi Relevan terhadap Kualitas Informasi Akuntansi}

Informasi yang relevan dikatakan jika informasi yang dihasilkan tersebut bisa menjadi dasar dalam pengambilan keputusan (Hilton, et al., 2000). Informasi harus relevan untuk memenuhi kebutuhan pemakai dalam proses pengambilan keputusan. Informasi memiliki kualitas relevan kalau dapat mempengaruhi keputusan ekonomi pemakai dengan membantu mereka mengevaluasi peristiwa masa lalu, masa kini atau masa depan, menegaskan, atau mengkoreksi hasil evaluasi mereka dimasa lalu (IAI, 2015).

H2 : Karakteristik kualitas informasi akuntansi relevan berpengaruh secara signifikan terhadap kualitas informasi akuntansi.

\section{Pengaruh Karakteristik Kualitas Informasi Akuntansi dapat Diandalkan terhadap Kualitas Informasi Akuntansi}

Keandalan, yaitu Laporan keuangan bebas dari pengertian yang menyesatkan, kesalahan material, dan disajikan secara tulus dan jujur (faithful representation), dimana informasi yang andal apabila memenuhi karakteristik penyajian jujur, dapat diverifikasi dan netralitas (Diyana dan Julianto, 2009). Informasi akuntansi bisa dikatakan berkualitas apabila informasi tersebut bisa diandalkan (Suherman dan Suryani, 2008).

H3 : Karakteristik kualitas informasi akuntansi dapat diandalkan berpengaruh secara signifikan terhadap kualitas informasi akuntansi.

\section{Pengaruh Karakteristik Kualitas Informasi Akuntansi dapat Dibandingkan terhadap Kualitas Informasi Akuntansi}

Pemakai harus dapat membandingkan laporan keuangan perusahaan antara periode untuk mengidentifikasi kecenderungan posisi dan kinerja keuangan. Pemakai juga harus dapat memperbandingkan laporan keuangan antara perusahaan untuk mengevaluasi posisi keuangan secara relatif (IAI, 2015). Dimana suatu informasi dikatakan berkualitas apabila informasi tersebut dapat diperbandingkan, baik antar periode maupun antar entitas.

H4 : Karakteristik kualitas informasi akuntansi dapat dibandingkan berpengaruh secara signifikan terhadap kualitas informasi akuntansi.

\section{METODE PENELITIAN}

Penelitian ini merupakan penelitian kuantitatif, dengan lokasi pada 12 BMT di Kota Malang dan Kabupaten Malang (Singosari, Pakisaji, Sekarpuro, dan Bululawang). Teknik pengambilan sampel dengan purposive sumpling di mana terdapat karakteristik yang akan digunakan: (1) BMT yang telah membuat laporan 
keuangan, (2) BMT yang berada di wilayah Malang Raya, (3) BMT yang bersedia mengembalikan kuisionernya. Data diambil dari kuisioner penelitian dengan menggunakan skala likert. Beriktu ini operasional variable dengan indikatornya:

Tabel 1. Definisi Operasional Variabel: Variabel, Sub-Variabel, Indikator, Skala

\begin{tabular}{|c|c|c|c|}
\hline Variabel & Kriteria & Indikator & Skala \\
\hline $\begin{array}{l}\text { Dapat Dipahami } \\
\left(\mathrm{X}_{1}\right)\end{array}$ & & 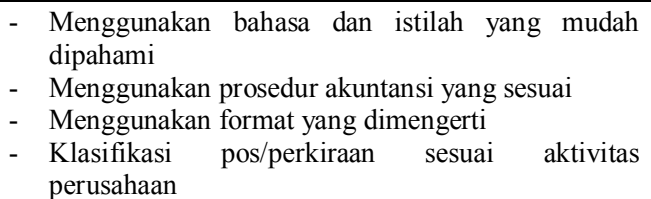 & Ordinal \\
\hline \multirow[t]{3}{*}{ Relevan $\left(\mathrm{X}_{2}\right)$} & Nilai prediksi & $\begin{array}{l}\text { - Untuk memprediksi sumber ekonomi, kewajiban } \\
\text { masa kini dan masa datang } \\
\text { - Dijadikan sebagai dasar pengambilan keputusan } \\
\text { - Menentukan perkiraan secara tepat } \\
\text { - Bermanfaat sebagai alat koreksi }\end{array}$ & Ordinal \\
\hline & $\begin{array}{l}\text { Nilai Konfirmasi, } \\
\text { Materialitas }\end{array}$ & $\begin{array}{l}\text { - Untuk penilaian kinerjamanajemen } \\
\text { - } \text { Mempercepat pengambilankeputusan } \\
\text { - } \text { Membantu memecahkan masalah } \\
\text { - } \text { Kelalaian atau kesalahan pernyataan dapat } \\
\text { mempengaruhi keputusan ekonomi pengguna. }\end{array}$ & Ordinal \\
\hline & Tepat Waktu & $\begin{array}{ll}\text { - } & \text { Tersedia saat diperlukan } \\
\text { - } & \text { Ukuran waktu ditetapkan } \\
\text { - } & \text { Didasarkan atas periodisasi yang ditetentukan }\end{array}$ & Ordinal \\
\hline \multirow[t]{4}{*}{ Keandalan $\left(\mathrm{X}_{3}\right)$} & Dapat diperiksa & $\begin{array}{ll}\text { - } & \text { Transaksi didukung oleh bukti yang lengkap } \\
\text { - } & \text { Dihasilkan dari prosedur dan metode yang teliti } \\
\text { - } & \text { Teruji kebenaran dengan standar yang ditetapkan } \\
\text { - } & \text { Jelas menggambarkan maksutnya }\end{array}$ & Ordinal \\
\hline & Objektif & $\begin{array}{l}\text { - Bebas dari perilaku yang bermotifekonomi, social, } \\
\text { politik } \\
\text { - Berorientasi kepada kebutuhan umum }\end{array}$ & Ordinal \\
\hline & $\begin{array}{l}\text { Menyajikan yang } \\
\text { seharusnya }\end{array}$ & $\begin{array}{l}\text { - Pencatatan didasarkan pada bukti dan dokumen } \\
\text { yang seharusnya }\end{array}$ & Ordinal \\
\hline & & $\begin{array}{l}\text { - Angka-angka menunjukkan kondisi yang } \\
\text { sebenarnya } \\
\text { - } \text { Terbebas dari kesalahan dan bias }\end{array}$ & \\
\hline $\begin{array}{l}\text { Dapat } \\
\text { dibandingkan } \\
\left(\mathrm{X}_{4}\right)\end{array}$ & & $\begin{array}{l}\text { - } \quad \text { Tersaji untuk beberapa periode } \\
\text { - } \quad \text { Bisa menunjukkan persamaan dan perbedaan } \\
\text { - } \text { Disusun berdasar format standar } \\
\text { - Ada relevansi dengan periode sebelumnya } \\
\text { - Informasi dapat dibandingkan dengan periode } \\
\text { sebelumnya } \\
\text { - Informasi dapat dibandingkan dengan perusahaan } \\
\quad \text { lain }\end{array}$ & Ordinal \\
\hline $\begin{array}{l}\text { Kualitas } \\
\text { Informasi }\end{array}$ & & $\begin{array}{l}\text { - Informasi akuntansi yang berkualitas adalah dapat } \\
\text { dipahami }\end{array}$ & Ordinal \\
\hline Akuntansi (Y) & & $\begin{array}{l}\text { - Informasi akuntansi yang berkualitas adalah } \\
\text { relevan } \\
\text { - Informasi akuntansi yang berkualitas adalah dapat } \\
\text { diandalkan } \\
\text { - Informasi akuntansi yang berkualitas adalah dapat } \\
\text { dibandingkan }\end{array}$ & \\
\hline
\end{tabular}

El-Muhasaba, Vol. 7, No 2, Juli 2016 


\section{PEMBAHASAN}

Penelitian telah melakukan uji validitas dan reabilitas dengan hasil semua varibel penelitian yang ada pada kuisioner telah valid dan Reliabel. Selanjutnya tidak ada masalah dengan Uji Asumsi Klasik (Uji Normalitas, Uji Multikolonieritas, Uji Heteroskodestisitas, Uji Autokorelasi.

\section{Analisis Uji Regresi Berganda}

Hasil analisis regresi linier berganda dapat diperoleh persamaan regresi sebagai berikut:

$\mathrm{Y}_{1}=\mathrm{a}+\mathrm{b}_{1} \mathrm{X}_{1}+\mathrm{b}_{2} \mathrm{X}_{2}+\mathrm{b}_{3} \mathrm{X}_{3}+\mathrm{b}_{4} \mathrm{X}_{4}+\mathrm{e}$

$\mathrm{Y} 1=8,181-0,173 \mathrm{X}_{1}+0,106 \mathrm{X}_{2}+0,358 \mathrm{X}_{3}-0,254 \mathrm{X}_{4}+3,943$

Uji F (Simultan), menunjukkan tersebut $F_{\text {hitung }}$ lebih besar dari pada $f_{\text {tabel }}$ yakni $16.650>3,48$ atau sig $0,004<0,05$ sehingga dapat di simpulkan bahwa variabel bebas atau independen yaitu dapat dimengerti $\left(\mathrm{X}_{1}\right)$, relevan $\left(\mathrm{X}_{2}\right)$, dapat diandalkan $\left(\mathrm{X}_{3}\right)$, dan dapat dibandingkan $\left(\mathrm{X}_{4}\right)$ secara bersama-sama berpengaruh secara signifikan terhadap variabel terikat atau dependen yaitu kualitas informasi akuntansi pada BMT di Malang, seperti tampak pada tabel berikut:

\section{Tabel 2. Uji F (Simultan)}

ANOVA $^{\mathrm{b}}$

\begin{tabular}{llrrrrr}
\hline Model & & Sum of Squares & Df & Mean Square & F & Sig. \\
\hline 1 & Regression & 7.534 & 4 & 1.884 & 16.650 & $.004^{\mathrm{a}}$ \\
& Residual & .566 & 5 & .113 & & \\
\hline & Total & 8.100 & 9 & & & \\
\hline
\end{tabular}

a. Predictors: (Constant), $X 4, X 3, X 2, X 1$

b. Dependent Variable: $y$

Sumber:Data primer diolah 2016 dengan SPSS 16

Uji t (Partial) menunjukkan bahwa semua variabel X memiliki nilai signifikansi $<0,05(5 \%)$ yang berarti secara parsial variabel yang memiliki nilai signifikansi $<$ $0,05(5 \%)$ memiliki pengaruh signifikan terhadap variabel Kualitas Informasi Akuntansi (Y). Seperti tampak pada tabel berikut: 
Tabel 3. Uji T (Partial)

\begin{tabular}{|c|c|c|c|c|c|c|}
\hline \multirow{2}{*}{\multicolumn{2}{|c|}{ Model }} & \multicolumn{2}{|c|}{ Unstandardized Coefficients } & \multirow{2}{*}{$\begin{array}{c}\begin{array}{c}\text { Standardized } \\
\text { Coefficients }\end{array} \\
\text { Beta }\end{array}$} & \multirow[b]{2}{*}{$\mathbf{t}$} & \multirow[b]{2}{*}{ Sig. } \\
\hline & & B & Std. Error & & & \\
\hline \multirow[t]{5}{*}{1} & (Constant) & 8.181 & 3.943 & & 2.075 & .093 \\
\hline & $\mathrm{X}_{1}$ & -.173 & .066 & -.334 & -2.642 & .046 \\
\hline & $\mathrm{X}_{2}$ & .106 & .032 & .415 & 3.320 & .021 \\
\hline & $\mathrm{X}_{3}$ & .358 & .074 & .592 & 4.809 & .005 \\
\hline & $\mathrm{X}_{4}$ & -.254 & .077 & -.440 & -3.313 & .021 \\
\hline
\end{tabular}

a. Dependent Variable: $y$

Sumber: Data primer diolah 2016 dengan SPSS 16

\section{Pengaruh Karakteristik dapat Dimengerti terhadap Kualitas Informasi Akuntansi}

Dari hasil penelitian menunjukkan nilai koefisien yang negatif dari variabel dapat dimengerti sebesar $-0,173$ dengan nilai $t_{\text {hitung }}$ yang lebih besar dari $t_{\text {tabel }}$ sebesar - $2.642<-1,812$ dengan signifikansi sebesar $0,046<0,05$ hal ini menunjukkan bahwa pentingnya kualitas informasi yang telah ditampung dalam laporan keuangan adalah kemudahannya untuk segera dapat dipahami oleh pemakai. Pemakai dalam hal ini diasumsikan memiliki pengetahuan yang memadai tentang aktivitas ekonomi dan bisnis, akuntansi, serta kemauan untuk mempelajari informasi dengan ketekunan yang wajar. (IAI, 2015).

Semakin dapat dipahami informasi yang disajikan dalam laporan keuangan oleh pengguna dan dinyatakan dalam bentuk serta istilah yang sesuai dengan batas pemahaman para pengguna maka semakin baik dan berguna kualitas informasi akuntansi tersebut. Penelitian ini sejalan dengan yang dilakukan Aditya (2014) yang memperoleh hasil bahwa dimengerti (understandable) berpengaruh terhadap kualitas informasi akuntansi pada RSUD Ungaran.

Fakta di lokasi penelitian yaitu BMT di Malang dalam menghasilkan informasi akuntansi, masing-masing responden BMT telah menggunakan bahasa indonesia yang sama. Ditambah lagi responden dari BMT yang rata-rata sudah lulusan sarjana, dimana sarjana memiliki kompetensi dalam mengevaluasi dan menganalisis, maka membuat responden terbantu untuk bisa memahami informasi akuntansi dari laporan keuangan yang telah dihasilkan.

Dari hasil diatas dalam Islam diterangkan dimana dapat dimengerti tersebut berhubungan dengan amanat yang akan disampaikan dalam informasi akuntansi, berdasar dalam Surat Al-Anfal Ayat 27:

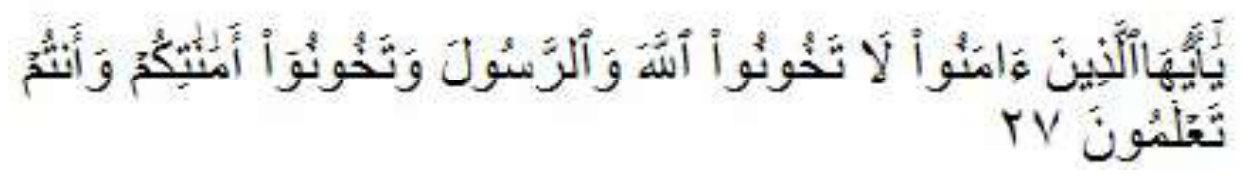

El-Muhasaba, Vol. 7, No 2, Juli 2016 
Hai orang-orang yang beriman, janganlah kamu mengkhianati Allah dan Rasul (Muhammad) dan (juga) janganlah kamu mengkhianati amanatamanat yang dipercayakan kepadamu, sedang kamu mengetahui(Al-Anfal; 27)

Berdasar tafsif Ibnu Katsir menjelaskan surat Al-Anfal: 27 yang dimaksud dengan amanat ialah meninggalkan perintah-Nya dan mengerjakan kemaksiatan.

Muhammad ibnu Ishaq mengatakan, telah menceritakan kepadaku Muhammad ibnu Ja' far ibnuz Zubair, dari Urwah ibnuz Zubair sehubungan dengan makna ayat ini, yaitu 'janganlah kalian menampakkan kebenaran di hadapannya yang membuatnya rela kepada kalian, kemudian kalian menentangnya dalam hati kalian dan cenderung kepada selainnya; karena sesungguhnya hal tersebut merusak amanat kalian dan merupakan suatu pengkhianatan terhadap diri kalian sendiri. As-Saddi mengatakan, apabila mereka mengkhianati Allah dan Rasul-Nya, berarti mereka mengkhianati amanat-amanat yang dipercayakan kepada diri mereka. Selanjutnya ia mengatakan pula bahwa dahulu mereka mendengar pembicaraan dari Nabi SAW., lalu mereka membocorkannya kepada kaum musyrik.

Kaitannya dengan variabel ini adalah dalam menyampaikan suatu informasi supaya menyamaikan dengan yang sebenarnya dalam arti informasi tersebut dapat dimengerti secara cepat oleh pembaca atau penerima informasi. Surat al anfal menurut tafsir diatas menjelaskan untuk tidak mengkhianati amanat-amanat yang telah digenggam. Informasi yang telah disampaikan haruslah sesuai dan tidak membuat bingung penerima informasi tersebut sehingga tidak ada pertanyaan-pertanyaan yang menjelaskan tidak percayanya penerima informasi karena tidak tahu maksud dari informasi tersebut.

\section{Pengaruh Karakteristik Relevan terhadap Kualitas Informasi Akuntansi}

Dari hasil penelitian secara parsial menunjukkan koefisien regresi untuk variabel relevan sebesar 0,106 dengan nilai $t_{\text {hitung }}$ yang lebih besar dari $t_{\text {tabel }} 3.320>1,812$ dengan signifikan $0,021<0,05$ sehingga dapat di simpulkan bahwa karakteristik kualitatif informasi akuntansi yang relevan berpengaruh signifikan positif terhadap kualitas informasi akuntansi hal ini menunjukkan bahwa semakin relevan informasi yang dihasilkan maka akan semakin baik kualitas informasi akuntansi yang dihasilkan.

Informasi yang berkualitas tersebut disebabkan karena informasi tersebut bermanfaat, informasi yang bermanfaat harus relevan untuk memenuhi kebutuhan pemakai dalam proses pengambilan keputusan. Suatu informasi akan dianggap memiliki nilai relevansi apabila dapat mempengaruhi keputusan ekonomi pengguna dengan cara membantunya mengevaluasi peristiwa masa lalu, masa kini, atau masa depan, menegaskan atau mengoreksi hasil evaluasinya di masa lalu. (Rudianto, 2012;21). 
Relevansi informasi akuntansi pada BMT di Malang Raya berdasar penelitian sudah menunjukkan bahwa informasi yang dihasilkan sudah relevan. Relevan tersebut dikarenakan informasi tersebut bisa dijadikan landasan pengambilan keputusan. Responden dari masing-masing BMT dalam penelitian ini adalah bagian yang membuat laporan keuangan yaitu bagian akuntansi. Dimana bagian akuntansi juga memiliki tugas memberikan analisis bila diperlukan dan memberikan masukan pada Rapat Badan Pengurus mengenai perkembangan BMT dari hasil laporan keuangan yang ada. Dari penjelasan diatas diketahui bahwa informasi akuntansi BMT sudah digunakan responden dalam membantu pengambilan keputusan dan alat koreksi pada BMT di Malang, itu membuat bahwa informasi akuntansi pada BMT di Malang sudah relevan.

Salah satu responden juga menerangkan bahwatingkat keakurasian sebuah informasi data keuangan sangat berpengaruh terhadap kualitas informasi akuntansi keuangan yang diberikan, karena data-data yang diterima harus sesuai dengan buktinya. Data tersebut berupa data harian yang dientry oleh kasir yang berisi bukti-bukti transaksi, dll. Sebelum laporan tersebut disajikan terlebih dahulu dilakukan koreksi oleh bagian keuangan, apabila terjadi kesalahan atau tidak sesuai maka laporan tersebut akan dikembalikan kebagian kasir untuk dilakukan konfirmasi perbaikan.

Ditambah lagi unsur relevansi dari ketepatan waktu pelaporan keuangan BMT di Malang telah tepat waktu dimana telah ditetapkannya batasan waktu pelaporan keuangan yang harus dilaporkan oleh bagian keuangan dari BMT berdasar kebijakan masing-masing BMT. Hal itu membuat informasi akuntansi dari laporan keuangan yang dibutuhkan oleh manajemen BMT guna dijadikan sebagai dasar pengambilan keputusan menjadi relevan dan lebih akurat.

Kaitannya hasil ini dengan perspektif Islam bisa dijelaskan dalam surat At Taubah ayat 106:

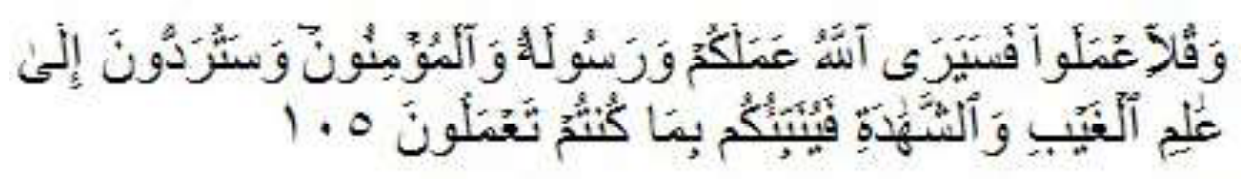

Dan Katakanlah: "Bekerjalah kamu, maka Allah dan Rasul-Nya serta orang-orang mukmin akan melihat pekerjaanmu itu, dan kamu akan dikembalikan kepada (Allah) Yang Mengetahui akan yang ghaib dan yang nyata, lalu diberitakan-Nya kepada kamu apa yang telah kamu kerjakan (At Taubah 105)

Dalam tafsir Ibnu katsir dijelaskan Mujahid mengatakan bahwa hal ini merupakan ancaman dari Allah terhadap orang-orang yang menentang perintahperintah-Nya, bahwa amal perbuatan mereka kelak akan ditampilkan di hadapan Allah SWT dan Rasul-Nya serta orang-orang mukmin. Oleh karena itu kita dalam 
berbuat sesuatu harus melihat apakah perbuatan yang akan kita lakukan bermanfaat untuk orang lain atau diri sendiri atau tidak, karena perbuatan yang bermanfaat adalah perbuatan yang relevan.

Hubungannya pada informasi yang relevan adalah penyampaian infomasi haruslah dilakukan secara relevan yang mana apa yang tersampaikan harus bisa ditangut bisa berguna untuk pihak-pihak yang berkepentingan. Relevan juga di pengaruhi oleh hakikat dan tingkat materialitasnya. Materialitas ditentukan berdasarkan pengaruh kelalaian (ambang batas) terhadap keputusan ekonomi pemakai yang diambil atas dasar laporan keuangan. Oleh karena itu, materialitas dipengaruhi oleh besarnya kesalahan dalam mencantumkan atau pencatatan.

\section{Pengaruh Karakteristik tapat Diandalkan terhadap Kualitas Informasi Akuntansi}

Dari hasil penelitian secara parsial menunjukkan koefisien regresi untuk variabel dapat diandalkan sebesar 0,358 dengan nilai $t_{\text {hitung }}$ yang lebih besar dari $t_{\text {tabel }} 4.809$ $>1,812$ dengan signifikan $0,005<0,05$ sehingga dapat di simpulkan bahwa karakteristik kualitatif informasi akuntansi yang dapat diandalkan berpengaruh signifikan positif terhadap kualitas informasi akuntansi, hal ini menunjukkan bahwa semakin dapat diandalkan informasi yang dihasilkan maka akan semakin baik kualitas informasi akuntansi yang dihasilkan.

Hal ini disebabkan karena suatu informasi harus dapat diandalkan dalam mendukung suatu pengambilan keputusan sehingga menghasilkan suatu keputusan yang solid, sesuai dengan kebutuhan dan keadaan perusahaan. Informasi yang andal haruslah dapat diperiksa, memiliki nilai kejujuran dan netralitas. (Diyana dan Julianto, 2009) Informasi mungkin relevan tetapi jika hakekat atau penyajiannya tidak dapat diandalkan maka penggunaan informasi tersebut secara potensial dapat menyesatkan. Misalnya jika tindakan hukum masih dipersengkatakan, mungkin tidak tepat bagi perusahaan untuk mengakui jumlah seluruh tuntutan tersebut dalam laporan posisi keuangan, meskipun mungkin tepat untuk mengungkapkan jumlah serta keadaan dari tuntutan tersebut. (IAI, 2015)

Seperti yang dikatakan dalam penelitian terdahulu bahwa informasi akuntansi bisa dikatakan berkualitas apabila informasi tersebut bisa diandalkan. (Suherman dan Suryani, 2008)

Melihat realita di lokasi penelitian yaitu BMT di Malang Raya, dimana pembuat dan pengguna informasi akuntansi selain adalah seorang sarjana, responden juga sudah berpengalaman di bidang keuangan lebih dari 5 tahun. Hal ini menunjukkan bahwa mereka bisa dikatakan berpengalaman dalam menghasilkan informasi akuntansi. Dalam proses pembuatan informasi akuntansi, sifat andal dan terpercaya sudah menjadi standar bagi mereka sebagai seorang sarjana ekonomi yang sudah melekat pada responden di BMT Malang Raya, maka harus mempertanggung 
jawabkan profesi akuntan mereka dan dalam menyampaikan laporan keuangan harus jujur dalam penyajian, netral, dan selengkap-lengkapnya.

Kemudiandiperkuat lagi BMT di Malang rata-rata sudah memiliki Internal Auditor yang melakukan pengawasan secara periodik atas aktivitas menejemen, operasional dan keuangan dan ketepatan waktu pelaporan keuangan BMT di Malang sudah tepat waktu dimana telah ditetapkannya batasan waktu pelaporan keuangan yang harus dilaporkan oleh bagian keuangan dari BMT berdasar kebijakan masingmasing BMT.

Keandalan dalam Islam merujuk pada bagaimana dalam menyampaikan amanat dengan jujur dan apa adanya. Seperti yang dijelaskan di surat An-Nisa' ayat 58:

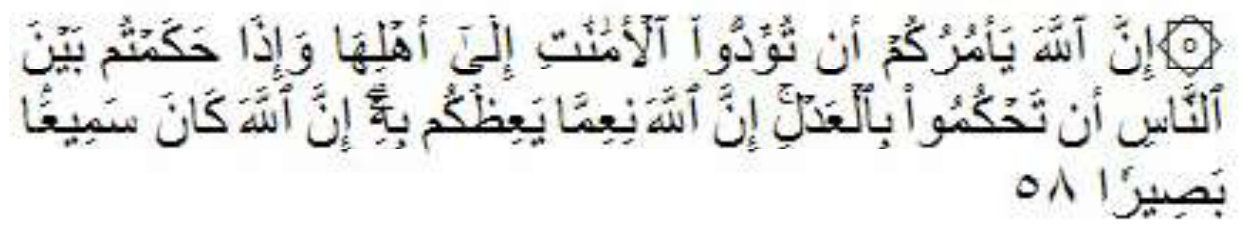

Sesungguhnya Allah menyuruh kamu menyampaikan amanat kepada yang berhak menerimanya, dan (menyuruh kamu) apabila menetapkan hukum di antara manusia supaya kamu menetapkan dengan adil. Sesungguhnya Allah memberi pengajaran yang sebaik-baiknya kepadamu. Sesungguhnya Allah adalah Maha Mendengar lagi Maha Melihat (An-Nisa';58)

Dalam Tafsir Quraish Shihab dijelaskan sesungguhnya Allah memerintahkan kalian, wahai orang-orang yang beriman, untuk menyampaikan segala amanat Allah atau amanat orang lain kepada yang berhak secara adil. Jangan berlaku curang dalam menentukan suatu keputusan hukum. Ini adalah pesan Tuhanmu, maka jagalah dengan baik, karena merupakan pesan terbaik yang diberikan-Nya kepada kalian. Allah selalu Maha Mendengar apa yang diucapkan dan Maha Melihat apa yang dilakukan. Dia mengetahui orang yang melaksanakan amanat dan yang tidak melaksanakannya, dan orang yang menentukan hukum secara adil atau zalim. Masing-masing akan mendapatkan ganjarannya.

Dalam kaitannya dengan Informasi akuntansi yang andal adalah bahwa informasi yang dihasilkan haruslah sesuai dengan fakta yang ada. Dimana dalam informasi tersebut bisa dipegang amanatnya sebagai informasi yang benar dan bersih dari sifat-sifat kecurangan. Kualitas informasi akuntansi ini jika berpegang terhadap ayat tersebut akan menjadi informasi yang andal dan terpercaya.

\section{Pengaruh Karakteristik dapat Dibandingkan terhadap Kualitas Informasi Akuntansi}

Dari hasil penelitian secara parsial menunjukkan koefisien regresi untuk variabel dapat dibandingkan sebesar 0,254 dengan nilai $t_{\text {hitung }}$ yang lebih besar dari $t_{\text {tabel }}-3,313$ 
$>-1,812$ dengan signifikan $0,021<0,05$ sehingga dapat di simpulkan bahwa karakteristik kualitatif informasi akuntansi yang dapat dibandingkan berpengaruh signifikan negatif terhadap kualitas informasi akuntansi, hal ini disebabkan dalam pengukuran dan penyajian dampak keuangan, transaksi, dan peristiwa lain yang serupa harus dilakukan secara konsisten untuk perusahaan bersangkutan, antar periode perusahaan yang sama dan untuk perusahaan yang berbeda. (IAI,2015)

Suatu informasi akan menjadi lebih berguna apabila dapat dibandingkan dengan informasi sejenis dari perusahaan lainnya (keterbandingan) dan dapat dibandingkan dengan informasi serupa dalam satu perusahaan pada titik waktu yang berbeda. (Belkaoui, 2006) Karena itu, pengguna laporan keuangan juga harus mendapat informasi tentang kebijakan akuntansi yang digunakan dalam penyusunan laporan keuangan, perubahan kebijakan akuntansi, dan pengaruh dampak perubahan tersebut. (Rudianto, 2012;22)

BMT di Malang dalam karakteristik dapat dibandingkan sudah sejalan dengan standar yang sudah ditetapkan dalam KDPPLK Syariah. Laporan keuangan yang dihasilkan sudah disusun dengan format standar yang sama sehingga informasi akuntansi tersebut bisa dibandingkan antar periode dengan mudah. Selain itu responden penelitian ini hanya terdiri dari 10 BMT di Malang yang dari sudut pendidikan dan keterampilan manajemen serta pemahaman akuntansi yang relatif sama. Hal tersebut karena adanya koordinasi yang cukup intensif dari Dinas Koperasi, Koperasi Syariah dan Koperasi Umum lain, sehingga dari segi responden relatif homogen. Dari penelitian terlihat cukup jelas bahwa BMT di Malang Raya yang perkembangannya cukup baik sudah mampu menyediakan informasi akuntansi, seperti laporan keuangan baik bulanan maupun tahunan dan secara rutin mampu memberikan laporan kegiatannya ke Dinas Koperasi sebagai intitusi yang menaungi koperasikoperasi seperti BMT di Malang.

Dapat dibandingkan dalam Islam sendiri bisa diketahui bagaimana suatu informasi haruslah sesuai standar pengukuran yang telah ditetapkan dan taat pada asas yang telah ditetapkan sehingga informasi tersebut bisa dibandingkan satu sama lain. Seperti dalam surat Al-Israa' ayat 35:

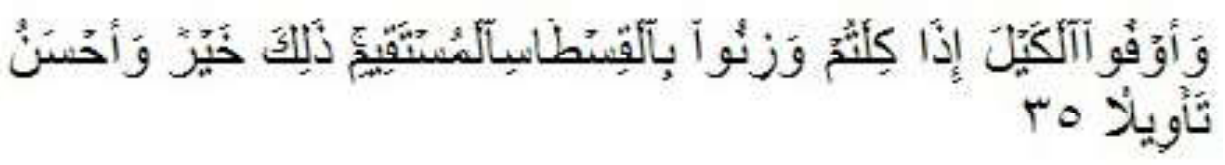

Dan sempurnakanlah takaran apabila kamu menakar, dan timbanglah dengan neraca yang benar. Itulah yang lebih utama (bagimu) dan lebih baik akibatnya ( Al-Israa';35)

Tafsir Ibnu Katsir dijelaskan sempurnakanlah takaran yakni tidak boleh menguranginya di dalam neraca timbangan. Maka bisa ditarik kesimpulan dalam 
akidah akuntansi dalam konsep Islam dapat didefinisikan sebagai kumpulan dasar hukum yang baku dan permanen. Disimpulkan dari sumber-sumber Syariah Islam dan dipergunakan sebagai aturan oleh seorang Akuntan dalam pekerjaannya, baik dalam pembukuan, analisis, pengukuran, pemaparan, maupun penjelasan, dan menjadi pijakan dalam menjelaskan suatu kejadian atau peristiwa. Sehingga dengan adanya sumber dasar hukum dalam pencatatan yang telah ditetapkan maka informasi akuntansi tersebut bisa konsisten dalam pencatatannya dan nantinya bisa untuk dibandingkan satu sama lainnya.

Uji Koefisien Determinasi $\left(\mathbf{R}^{2}\right)$ menunjukkan Koefesien determinasi yang di lihat dari kolom adjust $r$ squre sebesar 0,805 hal ini menunjukkan kemampuan variable t dalam menjelaskan variable independen terhadap dependennya sebesar $80,5 \%$ dan sisanya sebesar $19,5 \%$ di tentukan oleh variabe lain di luar oleh variabel independen dari penelitian ini dan Standart eror dalam memprediksi variable dependenya sebesar $41,93 \%$. Seperti tampak pada tabel berikut:

Tabel 4. Hasil Uji R

\begin{tabular}{lrrrr}
\hline Model & R & R Square & $\begin{array}{c}\text { Adjusted R } \\
\text { Square }\end{array}$ & $\begin{array}{l}\text { Std. Error of } \\
\text { the Estimate }\end{array}$ \\
\hline 1 & $.944^{\mathrm{a}}$ & .891 & .805 & .41936 \\
\hline
\end{tabular}

a. Predictors: (Constant), X4, X3, X2, X1

b. Dependent Variable: $y$

Sumber: Data Primer Diolah 2016 dengan SPSS 16

\section{SIMPULAN}

Berdasarkan uji parsial menunjukkan bahwa dapat dipahami berpengaruh signifikan terhadap kualitas informasi akuntansi, hal ini dikarenakan informasi yang dihasilkan dari laporan keuangan menggunakan bahasa dan istilah yang mudah dipahami serta format laporan keuangan yang mudah dipahami oleh responden yang notabene $80 \%$ adalah seorang sarjana. karakteristik kualitatif informasi akuntansi yang relevan berpengaruh signifikan positif terhadap kualitas informasi akuntans, hal ini dikarenakan informasi tersebut bisa dijadikan landasan pengambilan keputusan. Responden dari masing-masing BMT dalam penelitian ini adalah bagian yang membuat laporan keuangan yaitu bagian akuntansi. Dimana bagian akuntansi juga memiliki tugas memberikan analisis bila diperlukan dan memberikan masukan pada Rapat Badan Pengurus mengenai perkembangan BMT dari hasil laporan keuangan yang ada yang nantinya dijadikan dasar pengambilan keputusan, karakteristik kualitatif informasi akuntansi yang dapat diandalkan berpengaruh signifikan positif terhadap kualitas informasi akuntansi, hal ini dikarenakan pembuat dan pengguna informasi akuntansi selain adalah seorang sarjana, responden juga sudah berpengalaman di bidang keuangan lebih dari 5 tahun. Dalam proses pembuatan informasi 
akuntansi, sifat andal dan terpercaya sudah menjadi standar bagi mereka sebagai seorang sarjana ekonomi yang sudah melekat pada responden di BMT Malang Raya, karakteristik kualitatif informasi akuntansi yang dapat dibandingkan berpengaruh signifikan terhadap kualitas informasi akuntansi, hal ini dikarenakan laporan keuangan yang dihasilkan BMT di Malang sudah disusun dengan format standar yang sama sehingga informasi akuntansi tersebut bisa dibandingkan antar periode dengan mudah. Secara Simultan menunjukkan bahwa karakteristik kualitatif akuntansi yaitu dapat dimengerti, relevan, dapat diandalkan dan dapat dibandingkan berpengaruh secara signifikan terhadap kualitas informasi akuntansi pada BMT di Malang.

\section{DAFTAR PUSTAKA}

Al Quran dan Terjemahannya.

A, Djazuli, Yadi Janwari. 2002. Lembaga-Lembaga Perekonomian Umat (Sebuah Pengenalan). Jakarta: PT. Raja Grafindo Persada.

Aditya. 2014. Analisis Faktor-Faktor Yang Mempengaruhi Kualitas Informasi Akuntansi Pada Rumah Sakit Umum (Studi Pada Rumah Sakit Umum Daerah Ungaran). Fakultas Ekonomi dan Bisnis, Universitas Dian Nuswantoro.

Diyana, Julianto. 2014. Analisis Kualitas Informasi Akuntansi Keuangan Pada Pt.Pln (Persero) Wilayah Jawa Tengah. Jurnal Ilmiah UNTAG Semarang.

Donald E, Kieso, Jerry J. Weygandt dan Terry D. Warfield. (2013). Akuntansi Intermediate edisi 13. Jakarta: Erlangga.

Fahmi, Irham. 2011. Analisis Laporan Keuangan. ALFABETA, Lampulo.

Hendriksen, Van Breda. 2002. Teori Akuntansi. Batam: Penerbit Interaksa.

Hery. 2012. Analisis Laporan Keuangan. Jakarta: Bumi Aksara.

Hongren, et al. 1999. Management Accounting: Introduction to Management Accounting. Prentice-Hall Inc, New Jersey.

Huda, Nurul dan Mohamad Heykal. 2010. Lembaga Keuangan Islam. Jakarta: Kencana Prenada,

IAI. 2015. Pernyataan Standar Akuntansi Indonesia. Jakarta.

Imaniyati, Neni Sri. 2010. Aspek-aspek hukum BMT. Bandung: Citra Aditya bakti.

Indriani, Khoiriyah. 2010. Pengaruh Kualitass Pelaporan Keuangan Terhadap Informasi Asimetri. Universitas Jenderal Soedirman Purwokerto.

Kiswara, Endang. 2011. Nilai Relevan dan Reliabilitas Kegunaan-Keputusan Informasi Akuntansi Menurut SFAC No.2 dalam Penyajian Laporan Keuangan. PhD thesis, Universitas Diponegoro, Semarang.

Lillrank, Paul. 2003. The Quality of Information. International Journal of Quality \& Reliability Management Decision. vol. 20 No.6 pp. 691-703.

Nurmala. 2009. Hubungan Kualitas Informasi Akuntansi Keuangan Syariah Dengan Kinerja Keuangan Baitulmal Wattamwil (BMT) Di Kota Bandar Lampung

Ridwan, Muhammad. 2004. Manajemen Baitul Maal Wat Tamwil. Yogyakarta: UII Press.

Romney, Marshall B., dan Paul John Steinbart. 2006. Sistem informasi Akuntansi Edisi 9. Jakarta: Salemba Empat.

El-Muhasaba, Vol. 7, No 2, Juli 2016 
Sakti. 2013. Pemetaan Kondisi dan Potensi BMT. Jurnal al-Muzara'ah, Vol.I, No.1.

Suherman dan Suryani. 2008. Pengaruh Kualitas Informasi Akuntansi Terhadap Strategi Peningkatan Kinerja.

Sukmaningrum, Tantriani. 2012. Analisis Faktor-Faktor YangMempengaruhi Kualitas InformasiLaporan Keuangan Pemerintah Daerah(Studi Empiris Pada Pemerintah Kabupaten Dan KotaSemarang). Universitas Diponegoro.

Tafsir Ibnu Katsir.

El-Muhasaba, Vol. 7, No 2, Juli 2016 